\title{
Population dynamics of Aegla manuinflata Bond-Buckup and Santos 2009 (Decapoda: Aeglidae), an threatened species
}

\author{
Dinâmica Populacional de Aegla manuinflata Bond-Buckup e Santos 2009 \\ (Decapoda: Aeglidae), espécie ameaçada
}

\author{
André Trevisan ${ }^{1}$ and Sandro Santos ${ }^{2}$ \\ ${ }^{1}$ Departamento de Zoologia, Centro Politécnico, Instituto de Ciências Biológicas, Universidade Federal do \\ Paraná - UFPR, CP 19020, Jardim das Américas, CEP 81531-980, Curitiba, PR, Brazil \\ e-mail: trevisan_andre@yahoo.com.br \\ ${ }^{2}$ Departamento de Biologia, Universidade Federal de Santa Maria - UFSM, Avenida Roraima, 1000, \\ CEP 97105-900, Santa Maria, RS, Brazil \\ e-mail: sandro.santos30@gmail.com
}

\begin{abstract}
Aim: We evaluate the population density, median size of males and females, age distribution, sex-ratio, reproductive period and recruitment period of the threatened species Aegla manuinflata. Methods: Monthly samplings were made from May 2006 to April 2007 in the Passo Taquara stream, Brazil. An extra sampling was performed at each season of the year in order to determine population density. Animals were captured with traps and handnets. All the captured specimens were sexed and had their cephalotoraccic length measured with a digital caliper $(0.01 \mathrm{~mm})$, and were then released back in the stream. Results: A total of 888 individuals were analyzed, including 17 unsexed juveniles, 572 males, 274 females and 25 ovigerous females. A mean population density of $1.52 \mathrm{ind} / \mathrm{m}^{2}$ was estimated. Males showed median sizes larger than females $(\mathrm{p}<0.01)$. Age distribution was bimodal for both males and females. Females predominated in intermediary size-classes, while males were more abundant in the larger classes, with no differences for the lower classes. The sex-ratio, in general, followed the expected 1:1 proportion only in the months of May, October and November ( $p>0.05)$. Males and females caught only with handnet follow the expected 1:1 proportion in all months of the year $(\mathrm{p}>0.05)$, demonstrating that the sampling method clearly affects the results. Ovigerous females and juveniles were registered in all seasons of the year and there is no significant different in the proportion of these animals among the seasons $(p>0.05)$, indicating continuous reproduction. Conclusions: Population data of this study can be used as a basis for the creation of conservation measures of $A$. manuinflata, since the species is considered vulnerable.
\end{abstract}

Keywords: density, sex-ratio, reproductive period, recruitment, age distribution.

Resumo: Objetivo: $\mathrm{O}$ objetivo deste trabalho foi avaliar a densidade populacional, tamanho mediano de machos e fêmeas, distribuição etária, proporção sexual, período reprodutivo e de recrutamentoda espécie ameaçada Aegla manuinflata. Métodos: Foram realizadas coletas mensais de maio de 2006 a abril de 2007 no Arroio Taquara, município de São Pedro do Sul e uma coleta adicional por estação do ano para determinaçấo da densidade. Os animais foram coletados com armadilhas e puçá. Todos os exemplares capturados foram sexados e tiveram o comprimento cefalotorácico mensurado com um paquímetro digital com precisão de $0,01 \mathrm{~mm}$ e, em seguida, foram devolvidos ao riacho. Resultados: Foram analisados 888 indivíduos sendo 17 jovens não sexados, 572 machos, 274 fêmeas e 25 fêmeas ovígeras. Foi estimada uma densidade populacional média de 1,52 indivíduos por metro quadrado. Os machos apresentaram tamanho mediano superior ao das fêmeas $(\mathrm{p}<0,01)$. A distribuição etária se mostrou bimodal tanto para machos quanto para fêmeas. Fêmeas predominaram nas classes de tamanho intermediárias enquanto machos foram mais numerosos nas classes de tamanho superiores, não havendo diferenças nas classes inferiores. A proporção sexual geral seguiu a esperada de 1:1 somente nos meses de maio, outubro e novembro $(p>0,05)$. Machos e fêmeas quando coletados apenas com puça seguem a proporção esperada de 1:1 em todos os meses do ano $(p>0,05)$, o que deixa claro que o método de coleta interfere significativamente nos resultados. Fêmeas ovígeras e juvenis foramregistrados em todas as estaçōes do ano e não há diferença significativa na proporção destes animais entre uma estação e outra $(p>0,05)$, caracterizando uma reprodução contínua. Conclusóes: Os dados populacionais do presente estudo podem ser utilizados como base para a criação de medidas de conservaçáo de $A$. manuinflata, uma vez que a espécie é considerada vulnerável.

Palavras-chave: densidade, proporção sexual, período reprodutivo, recrutamento, distribuição etária. 


\section{Introduction}

Nowadays, the environmental changes caused by land use for anthropogenic activities are between the greatest causes for the extinction of species. Despite conservation efforts to reduce the loss of biodiversity, the later keeps decreasing over the last years (Rands et al., 2010; Giam et al., 2011).

Such scenario is even direr when considering species that are endemic or with very narrow geographical distributions. In such cases, local sources of pollution and activities in the catchment area of river basins can severely compromise the stability of these populations, since the narrower distribution may very well be the result of low dispersion capabilities and/or a smaller ability to withstand environmental changes, when compared to groups with broader distributions (Bradshaw et al., 2008; Trevisan et al., 2009; Giam et al., 2011).

The risk of extinction of a given species has been approached in two different ways: the first approach relates ecological and life-history traits of the groups who might be related to local extinctions, and the second approach including risk factors for global extinctions (Bradshaw et al., 2008; Olden et al., 2008; Giam et al., 2011). For the first type of approach, studies on population dynamics, especially for crustaceans, are of the upmost importance as they provide subsidies for the knowledge of the ecological stability of species in a given ecosystem, and can reveal the biological strategies used by the organism when facing its environment. In Decapoda (crabs, lobsters, shrimps, prawns, and others) population structure has been analyzed mainly through the distribution of individuals within size-classes (age distribution), sex-ratio, reproductive and recruitment periods, dispersion, birth and death rates, population density, among others (Trott, 1996; NegreirosFransozo et al., 1999; Baptista et al., 2003; Branco and Fracasso, 2004; Masunari, 2006).

Aegla manuinflata Bond-Buckup and Santos, 2009 is a recently described species, known only for the central region of the Rio Grande do Sul state (Brazil), and found in only three low-order tributaries of the Ibicuí-Mirim river. Due to these traits, the species is already described as "vulnerable". At a recently review, the species was re-classified as Endangered (EN) because its extent of occurrence (EOO) is lesser than $5.000 \mathrm{~km}^{2}\left(2.830 \mathrm{~km}^{2}\right)$ and its area of occupancy (AOO) is lesser than $500 \mathrm{~km}^{2}$ $\left(12 \mathrm{~km}^{2}\right)$; it is found in three sites, in areas of continuing decline in habitat quality, meeting the criteria B1ab(iii)+2ab(iii) (Santos and Bueno, in preparation).

In the latter decades, a considerable amount of information regarding the biology and population structure of aeglids has been published (Bahamonde and Lopez, 1961; López, 1965; Rodrigues and Hebling, 1978; Bueno and Bond-Buckup, 2000; Swiech-Ayoub and Masunari, 2001a, b; Noro and Buckup, 2002; Fransozo et al., 2003; Colpo et al., 2005; Gonçalves et al., 2006). More recently, new approach es have been adopted in the evaluation of population parameters, such as estimating population size (Bueno et al., 2007) or investigating the genetic structure of populations that are next to one another, but geographically isolated (Bartholomei-Santos et al., 2011). However, the traditional techniques have not been abandoned (Cohen et al., 2011; Teodósio and Masunari, 2009).

The goal of this study is to evaluate aspects related to population dynamics of $A$. manuinflata, as subsidies for the creation of future strategies for the conservation of this species.

\section{Material and Methods}

The Taquara Stream (2936'01" S; 54 $10^{\prime} 37^{\prime \prime}$ W; heigth $=158 \mathrm{~m}$ above sea level) is a tributary belonging to the Ibicuí-Mirin River Basin, which in turn belongs tothe Uruguay River Basin. The stream did not possess riparian vegetation in most of the sampled portion, because the study area is employed for cattle ranching (Figure 1).

Monthly samplings were performed from May 2006 to April 2007, in a section of the stream of approximately $240 \mathrm{~m}$ of length. The organisms were collected with 25 traps made of plastic bottles, and using bovine liver as bait: traps were laid in the stream in one day, and recovered in the morning of the following day. Samples were also made with a handnet $(30 \mathrm{x} 40 \mathrm{~cm}$ opening, $60 \mathrm{~cm}$ depth and $0.2 \mathrm{~mm}$ mesh size), with a $40 \mathrm{~min}$ sampling effort by two researchers for each monthly sampling. Te captured individuals were sexed through the presence of pleopods for females, and absence for males and/or through the genital pores (in the coxa of the $3^{\text {rd }}$ pleopod in females, and in the $5^{\text {th }}$ for males) (Martin and Abele, 1988). When visualization of these structures was not possible with a naked eye, a magnifying glass was used. Individuals with less than $3 \mathrm{~mm}$ of cephalotoracic length were considered as unsexed juveniles, as their pelopods and genital pores were too undeveloped to provide a reliable identification of the animal's sex. 


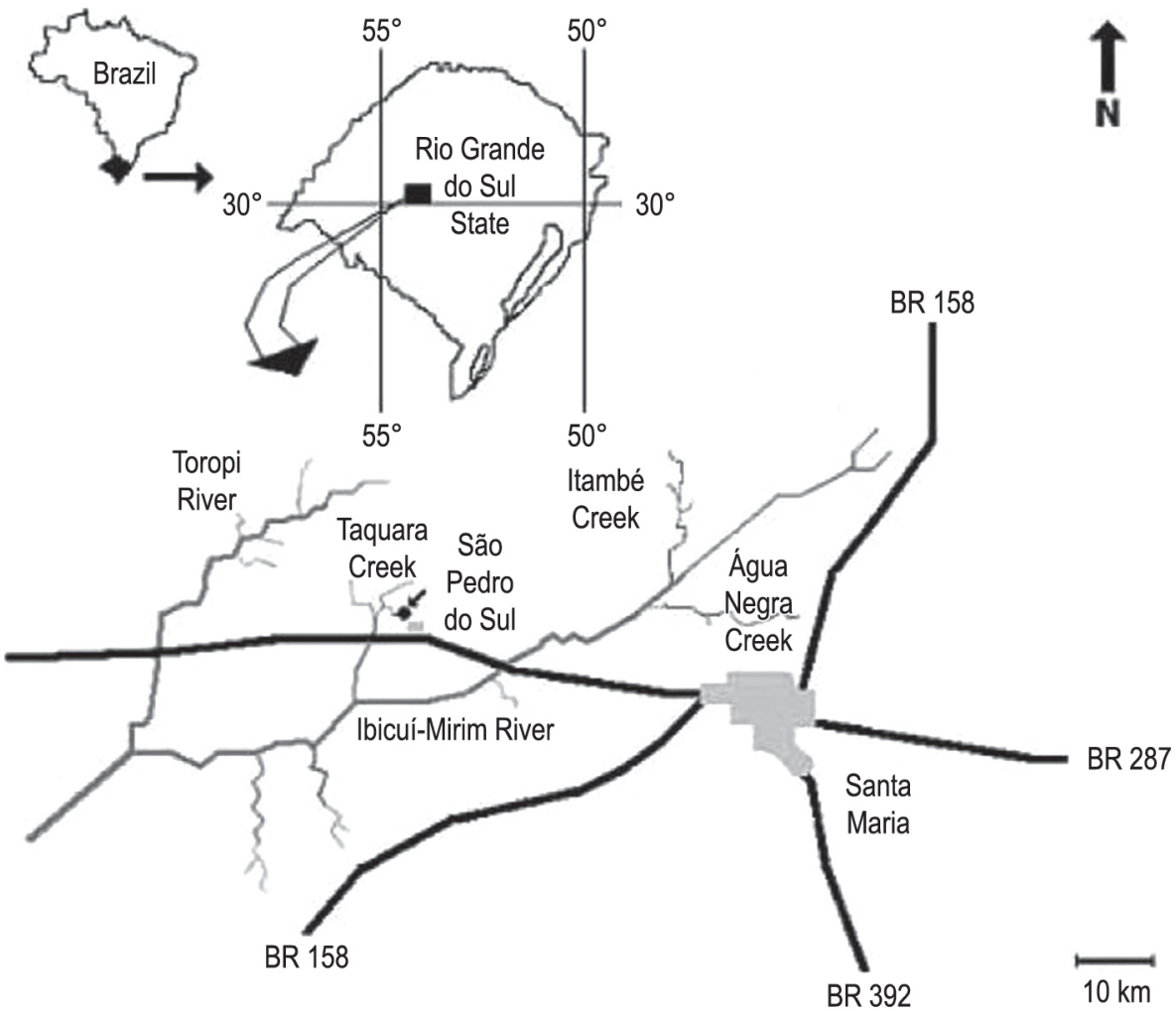

Figure 1. Schematic representation of the location of the Passo Taquara stream in the central region of the Rio Grande do Sul state, Brazil.

All captured organisms were measured for the cephalotoraccic length (CL - from the tip of the rostrum to the posterior edge of the carapace) with a digital caliper ( $0.01 \mathrm{~mm}$ accuracy). They were then released in the same sites where they were captured. Animals were considered as juveniles when CL was below $13.60 \mathrm{~mm}$ for males, and $12.34 \mathrm{~mm}$ for females, according to the estimate of morphological sexual maturity by Trevisan and Santos (2012).

The minimum, maximum, mean and median size (CL) of He captured animals were determined. The medians of males and females were compared through a Mann-Whitney test, with a significance level of 5\% (Zar, 1996).

For the determination of the frequency distribution of the size-classes, males and females were organized in classes with a $2 \mathrm{~mm}$ interval, corresponding to $1 / 4$ of the standard deviation of the CL of all animals sampled (Markus, 1971). The normality of these distributions was analyzed with a Shapiro-Wilk test (Zar, 1996).

The sex-ratio was evaluated for each size-class of CL, and monthly, in two different ways: The first considering all the sampled animals regardless of the capture method (grouped data), and the second considering only the individuals sampled with the handnet (excluding the data from traps). This was done to avoid a possible artifact of the sampling method, resulting from behavioral differences of males and females. For this parameter, we employed a Chi-squared test for expected proportions of $1: 1$, and a significance level of 5\% (Snedecor and Cochran, 1967).

The reproductive period and the recruitment were evaluated through the presence of juveniles and ovigerous females in each season of the year. To compare for differences in the proportion of ovigerous females and juveniles between the seasons, we employed an ANOVA with a 95\% confidence interval (Colpo et al., 2005).

Apart from these monthly samplings, additional ones (one per season of the year) were performed, in order to estimate the population density of A. manuinfalta. These collections initially followed the same procedure as the others: traps were laid in the stream in one day, and recovered in the morning of the following day. However, the captured animals were marked in the dorsal surface of the carapace using nail enamel, before being released back on the stream, in the end of the afternoon, traps were again 
laid on the stream, and recovered in the following morning.

For the estimation of the population size, we adopted Petersen's estimate, following Begon (1979): $\mathrm{N}=\mathrm{r} . \mathrm{n} / \mathrm{m}$, where: $\mathrm{N}=$ estimate of population size, $r=$ number of animals marked in the first day, $\mathrm{n}=$ number of animals captured in the second day, $\mathrm{m}=$ number of marked animals recaptured in the second day. The normal confidence interval was calculated for media with a significance level of $95 \%$ (Ayres et al., 2007).

\section{Results}

During the twelve sampling months, a total of 888 individuals were captured, being 17 unsexed juveniles, 572 males (145 juveniles and 427 adults) and 299 females (73 juveniles, 201 adults and 25 ovigerous) (Table 1). Population density for $A$. manuinflata was of 0.79 individuals per square meter $\left(\mathrm{ind} / \mathrm{m}^{2}\right)$ in the fall, $1.24 \mathrm{ind} / \mathrm{m}^{2}$ in the winter, $2.92 \mathrm{ind} / \mathrm{m}^{2}$ in the spring and $0.73 \mathrm{ind} / \mathrm{m}^{2}$ in the summer (mean $1.52 \pm 1.20 \mathrm{ind} / \mathrm{m}^{2}$ ) (Table 2).

The CL of the males ranged between 3.07 and $27.90 \mathrm{~mm}$, while the CL of females ranged from 3.20 to $24.12 \mathrm{~mm}$ (Table 3). The Mann-Whitney test showed a significant difference in the median CL size of males $(18.78 \mathrm{~mm})$ and females $(12.98 \mathrm{~mm})$, with males having larger sizes $(\mathrm{U}=43.22$; $\mathrm{p}<0.05)$.
The frequency distribution of the size-classes of the sampled animals was bimodal for both males and females of $A$. manuinflata (Figure $2 \mathrm{a}$ and $\mathrm{b}$ ), indicating the presence of two distinct age groups within the population.

Regarding the sex-ratio within the CL sizeclasses, it can be seen that males predominate in the larger classes, and females in the intermediary classes, with no differences for the lower classes. Based on the Chi-squared analysis, we can observe a significant predominance of males in all sizeclasses above $18.00 \mathrm{~mm}$ CL (class 10), for both the grouped data or data excluding the traps. All the animals registered for class $14(26.00 \nmid 28.00 \mathrm{~mm})$ were caught in traps. Although there were no difference for females in certain classes, these were more abundant than males in the classes $7(12.00-14.00 \mathrm{~mm})$ and $8(14.00+16.00 \mathrm{~mm})$ in both analyses (Figure 2a and b).

It was also observed a larger number of females, although not statistically significant, in the classes 2 (2.00 - 4.00), 3 (4.00 - 6.00), 4 (6.00 - 8.00), $5(8.00 \vdash 10.00)$ and $6(10.00 \vdash 12.00)$ for the grouped data analysis, and in classes 2 $(2.00 \vdash 4.00), 3(4.00 \vdash 6.00), 4$ (6.00 - 8.00) and $6(10.00-12.00)$ for the analysis including only data from handnet sampling.

When the sex-ratio was evaluated with grouped organisms, the sex-ratio was of 1.91 males for each

Table 1. Total number of individuals of Aegla manuinflata sampled with handnet and traps in the four seasons of the year ranging from May 2006 to April 2007 in the Passo Taquara stream, São Pedro do Sul, Rio Grande do Sul state, Brazil (MJ: Male juveniles, MA: Male adults, FJ: Female juveniles, FA: Female adults, OF: Ovigerous females).

\begin{tabular}{lcccccccccccc}
\hline Seasons & $\begin{array}{c}\text { MJ } \\
\text { Handnet }\end{array}$ & $\begin{array}{c}\text { MJ } \\
\text { Traps }\end{array}$ & $\begin{array}{c}\text { MA } \\
\text { Handnet }\end{array}$ & $\begin{array}{c}\text { MA } \\
\text { Traps }\end{array}$ & $\begin{array}{c}\text { FJ } \\
\text { Handnet }\end{array}$ & $\begin{array}{c}\text { FJ } \\
\text { Traps }\end{array}$ & $\begin{array}{c}\text { FA } \\
\text { Handnet }\end{array}$ & $\begin{array}{c}\text { FA } \\
\text { Traps }\end{array}$ & $\begin{array}{c}\text { FO } \\
\text { Handnet }\end{array}$ & $\begin{array}{c}\text { FO } \\
\text { Traps }\end{array}$ & $\begin{array}{c}\text { Indefined } \\
\text { Sex }\end{array}$ & Total \\
\hline Autumn & 21 & 01 & 18 & 69 & 9 & 9 & 43 & 11 & 01 & 03 & 15 & 200 \\
Winter & 56 & 04 & 69 & 65 & 13 & - & 39 & 14 & 05 & 05 & - & 270 \\
Spring & 38 & - & 18 & 63 & 20 & - & 45 & 06 & - & 03 & 1 & 194 \\
Summer & 01 & 24 & 17 & 108 & 22 & - & 35 & 08 & 03 & 05 & 1 & 224 \\
Total & 116 & 29 & 122 & 305 & 64 & 9 & 162 & 39 & 9 & 16 & 17 & $\mathbf{8 8 8}$ \\
\hline
\end{tabular}

Table 2. Aegla mauinflata. Quantitative data of the Petersen estimate of population density in the Passo Taquara stream, São Pedro do Sul, Rio Grande do Sul state, Brazil.

\begin{tabular}{lcccccc}
\hline Seasons & $\begin{array}{c}\text { Marked } \\
\text { (First Day) }\end{array}$ & $\begin{array}{c}\text { Recaptured } \\
\text { (Second Day) }\end{array}$ & $\begin{array}{c}\text { Recaptured } \\
\text { with marks }\end{array}$ & $\begin{array}{c}\text { Recaptured/Recaptured } \\
\text { whit marks }\end{array}$ & $\begin{array}{c}\text { Estimated } \\
\text { Population }\end{array}$ & ${\text { Ind } / \mathbf{m}^{2}}^{2}$ \\
\hline Spring & 26 & 22 & 3 & 7.33 & 190 & 0.79 \\
Summer & 46 & 39 & 6 & 6.5 & 299 & 1.24 \\
Autumn & 49 & 49 & 3 & 14.33 & 702 & 2.92 \\
Winter & 25 & 21 & 3 & 7.00 & 175 & 0.73 \\
\hline
\end{tabular}

Table 3. Descriptive measures for males and females of Aegla manuinflata in the Passo Taquara Stream, São Pedro do Sul, Rio Grande do Sul state, Brazil.

\begin{tabular}{ccccccc}
\hline Sex & $N$ & CC Mean & CC Median & SD & CC Minimum & CC Máximum \\
\hline Males & 572 & 16.96 & $18.78 \mathbf{a}$ & 5.91 & 3.07 & 27.90 \\
Females & 299 & 12.11 & $12.98 \mathbf{b}$ & 4.40 & 3.20 & 24.12 \\
\hline
\end{tabular}

$(\mathrm{CL}=$ cephalotoraccic length in $\mathrm{mm})$. Different letters indicate significant difference $(\mathrm{p}<0.05)$. 
female, being similar to the expected 1:1 proportion only in May, October and November ( $p>0.05)$; in the other months, the sex-ratio differed significantly from the expected, with a higher number of males $(\mathrm{p}<0.05)$ (Figure 3a). When only handnet captures were used for the sex-ratio analysis, the proportion was of $1.03: 1$, being statistically equivalent to the expected in all months ( $\mathrm{p}>0.05$ ) (Figure $3 \mathrm{~b}$ ).

A total of 25 ovigerous females were captured (8.36\%), out of a total of 299 females. Ovigerous females were present in all the seasons of the year, with a larger number of animals in the summer and fall, although these differences were not significant ( $p>0.05)$ (Figure 4). Juveniles were abundant in all the seasons of the year, with a higher number found in the winter and spring. Similarly to the ovigerous females, these differences were not statistically significant between the seasons ( $\mathrm{p}>0.05$ ) (Figure 4).
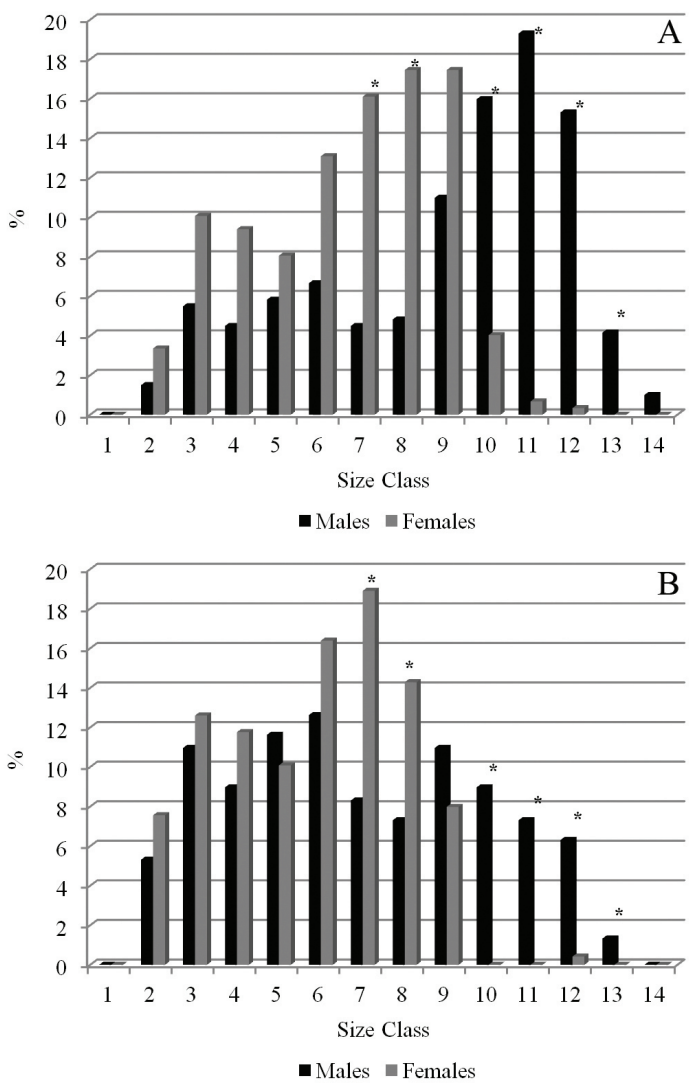

Figure 2. Distribution of the relative frequencies of cephalotoraccic length of males and females, and sexratio of the size-classes of Aegla manuinflata. A: All data included. B: Sex-ratio considering only animals caught in the handnet. Markings $\left(^{*}\right)$ indicate statistical difference in the sex-ratio $(\mathrm{p}<0.05)$. Size-classes $(\mathrm{mm})=1=0-$ $2 ; 2=2 \dashv 4 ; 3=4 \dashv 6 ; 4=6 \dashv 8 ; 5=8 \dashv 10 ; 6=10 \dashv$ $12 ; 7=12 \dashv 14 ; 8=14-16 ; 9=16-18 ; 10=18-20$; $11=20 \dashv 22 ; 12=22 \dashv 24 ; 13=24 \dashv 26 ; 14=26 \dashv 28$.

\section{Discussion}

Aegla manuinflata presents low population densities, with less than one individual per square meter in half of the total sampling time. The population density in the PassoTaquara Stream allows us to state that this species can still be classified as "EN" according to the IUCN criteria (International..., 2013). Besides, it can be found only in two other locations (Blackwater Stream and Itaimbé River) than the Passo Taquara Stream, indicating a very narrow and fragmented distribution. Other complications include the agricultural activities developed in the regions of the hydrographic basins where $A$. manuinflata occurs, which can affect water quality and, consequently, the survival of these populations (Santos et al., 2009).

A sexual dimorphism in relation to the median size of males and females was observed, with males having larger sizes. This had already been observed in other species of the genus, such as $A$. laevis laevis (Bahamonde and Lopez, 1961), A. paulensis
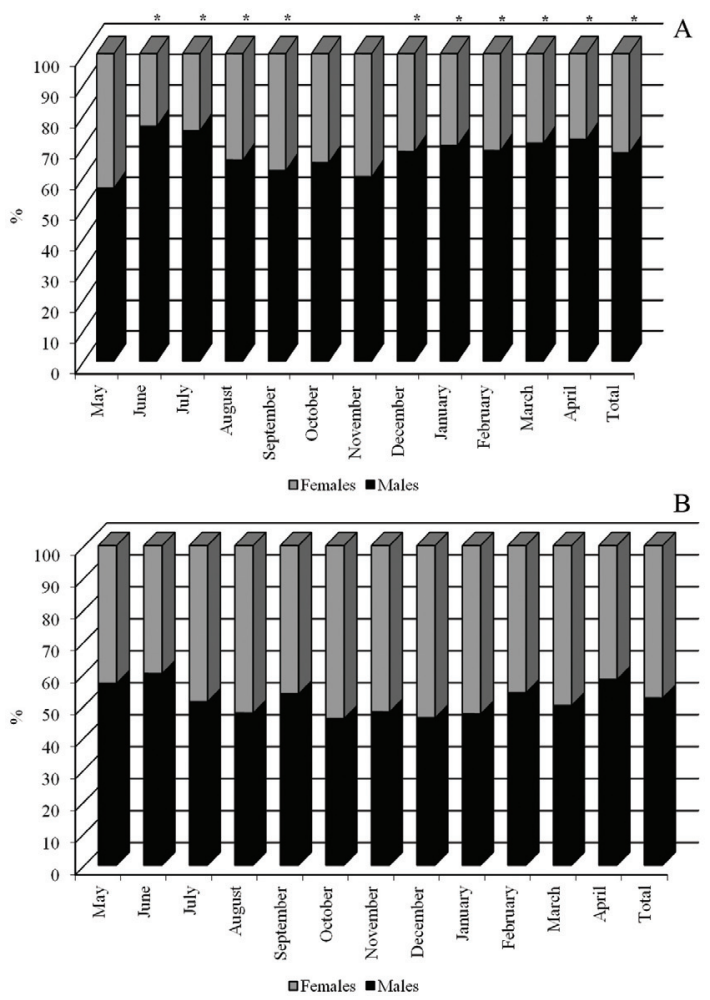

Figure 3. Aegla manuinflata: Sex-ratio of males and females captured in the Passo Taquara stream, São Pedor do Sul, Rio Grande do Sul state, Brazil. A: All data included. B: sex-ratio considering only animals caught in the handnet. Markings $\left(^{*}\right)$ indicate significant difference in the sex-ratio, according with the Chi-square test $(\mathrm{p}<0.05)$. 


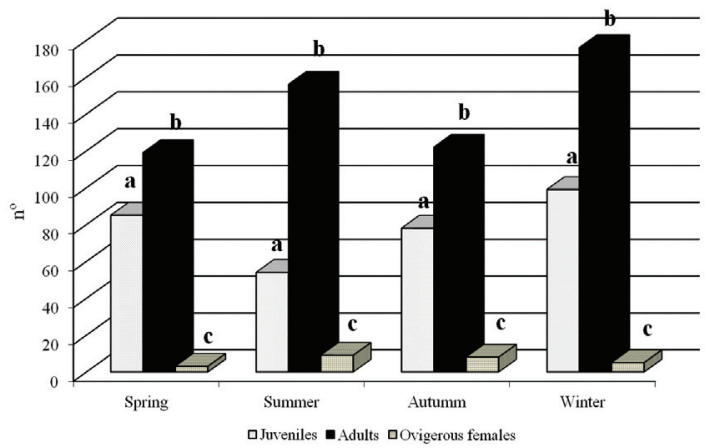

Figure 4. Aegla manuinflata: Relative frequencies of juveniles, adults and ovigerous females sampled in the four seasons of the year in the Passo taquara stream, São Pedro do Sul, Rio Grande do Sul state, Brazil (same letters indicate absence of significant differences between the frequencies of the categories between the seasons of the year [ANOVA; $\mathrm{p}>0.05$ ]).

(López, 1965), A. leptodactyla (Noro and Buckup, 2003), A. longirostri (Colpo et al., 2005), $A$. franciscana (Gonçalves et al., 2006) and $A$. schmitti (Teodósio and Masunari, 2009). On the other hand, Bueno et al. (2000) verified that the mean CL size of the females was higher than that of males of $A$. platensis, and Fransozo et al. (2003) did not observe differences in the mean sizes of males and females of $A$. castro.

Smaller sizes in the females of the genus Aegla may occur due to a reduction in the molt increment or an increase in the intermolt period during the reproductive period (Swiech-Ayoub and Masunari, 2001a). According to Passano (1960) and Hartnoll (1982) the growth of crustaceans is similar between the sexes just until they reach sexual maturity, after which the males tend to grow more due to the higher energetic expenditure of the females with egg incubation; in some species, females do not feed during this period. Other factors that also influence size differences between males and females in crustaceans are behavioral differences such as migrations, different responses to environmental perturbations and differentiated exploration of the resources in their habitats (Giesel, 1972; Montague, 1980).

Díaz and Conde (1989) state that bimodality or polimodality in the frequency distribution of size in crabs might be an indicator that intra and interspecific environmental factors such as recruitment peaks, differential of catastrophic mortality between the sexes or even ethological differences. The size-class distributions for males and females of $A$. manuinflata were bomodal, indicating more than one age group within the population. Patterns of polimodal distributions were already described for $A$. castro, $A$. longirostri and $A$. franciscana, studied by Fransozo et al. (2003), Colpo et al. (2005) and Gonçalves et al. (2006), respectively.

The sex-ratio within the size-classes of $A$. manuinflata followed the anomalous pattern described by Wenner (1972), with a predominance of females in the intermediary classes and males in the larger classes, for both the grouped data and the handnet data analyses. This fact might be associated to growth and events of the reproductive process such as gonad maturation and egg incubation, during which the somatic growth rate of females can remain inactive or even be reduced, resulting in their placement within the intermediary sizeclasses (Adiyodi and Adiyodi, 1970). The anomuran pattern was also quoted by Swiech-Ayoub and Masunari (2001a) in their study with $A$. castro and by Gonçalves et al., (2006) for $A$. franciscana.

According to Wenner (1972), the majority of decapod crustaceans shows a sex-ratio of 1:1. Changes on the population's sex-ratio may also be related to ethological differences between the sexes such as reproductive migrations, differential exploration of resources, distinct mortality rates between the sexes and intraspecific competition (Giesel, 1972).

In the current study, it can be inferred that the sampling method might alter the results of the sex-ratio in $A$. manuinflata, considering that when all data were employed, the sex-ratio differed from the expected and when only the handnet data were tested, this proportion was of 1:1 (male:female). During the trap samplings, it is observed that only large-sized males and, eventually, ovigerous females entered the traps, with juveniles only rarely being captured with this method. This observation can be associated to the fact that males are larger than females or juveniles, and these later would not enter the traps to avoid agonistic encounters with the larger males. According to Almerão et al. (2010), mature females release their eggs right after copulation and, being so, very few females could actually be with the males in the traps when these went to search for food. Another hypothesis is that the females do not feed during the copulation and, after that they require a rich source of nutrients, even if it implies competition with larger-sized males.

When the individuals caught in traps are excluded from the analysis, the sex-ratio follows 
the expected for all seasons of the year, with similar results being reported for $A$. laevis laevis, $A$ paulensis, $A$. platensis, $A$. leptodactyla, A. castro, $A$. longirostri, $A$. franciscana, $A$. schmitti and $A$. paulensis (Bahamonde and Lopez, 1961; López, 1965, Bueno and Bond-Buckup, 2000; Noro and Buckup, 2002; Fransozo et al., 2003; Colpo et al., 2005, Gonçalves et al., 2006, Teodósio and Masunari, 2009; Cohen et al., 2011, respectively). However, deviations of the sex-ratio are also recorded for the family, such as in the study by Rodrigues and Hebling (1978) with $A$. perobae.

The number of ovigerous females sampled was smaller than the number of non-ovigerous, which hás also been registered for other species of Aegla, demonstrating a natural trend of non-ovigerous females to numerically stand out within populations (Noro and Buckup, 2002; Fransozo et al., 2003; Gonçalves et al., 2006). The ovigerous females captured in the current study were mostly caught in traps and in the stream banks, where the waters are calmer, allowing the females to bury themselves on the substrate or to hide among the marginal vegetation, which might difficult their sampling. Similar observations were made by Bahamonde and Lopez (1961), López (1965) and Bueno and Bond-Buckup (2000).

Ovigerous females were sampled in all seasons of the year, with a higher frequency in the winter, which demonstrates that this species' reproductive period covers all the year. Similar results were reported by Bueno and Bond-Buckup (2000), who mention that the presence of ovigerous females throughout the whole year is associated to the abundance of food resources in the collection site, cooler temperatures $\left(13^{\circ} \mathrm{C}\right.$ in the winter and $22^{\circ} \mathrm{C}$ in the summer) and clear waters. Colpo et al. (2005) found that $A$. longirostri also reproduces year-round, with peaks in the spring and Summer. For other species, such as $A$. paulensis (López, 1965), A. leptodactyla (Noro and Buckup, 2002); A. castro (Fransozo et al., 2003) and $A$. franciscana (Gonçalves et al., 2006) the reproductive period is restricted to the colder months of the year.

Bueno and Shimizu (2008), in their study on the reproductive biology of $A$. franca females, performed an extensive revision of the factors responsible for the interspecific variation on the reproductive period of aeglids. They suggest that the reproductive patterns within the family might be associated to variations in latitude, temperature and rainfall, with species from higher latitudes possessing a longer reproductive period. In species from environments exposed to large variations in rainfall and smaller variations of temperature, the opposite occurs and the reproductive period tends to be shorter. Data corresponding to the reproductive period of the current study, associated with the geographical location and rainfall of the monitored region fit the pattern proposed by Bueno and Shimizu (2008).

Similarly, juveniles were observed in all seasons of the year, but with larger numbers in the winter and spring, which is another clue indicating that the reproductive period of $A$. manuinflata covers all year. The recruitment time is characterized by different periods, according to the species and area sampled. Colpo et al. (2005) determined that the recruitment period of $A$. longirostri in the central region of the Rio Grande do Sul state occurs from June to August, Bueno and Bond-Buckup (2000) observed the input of juveniles in the population during the spring, in the municipality of Taquara, Swiech-Ayoub and Masunari (2001a) observe the recruitment of $A$. castro during the spring and fall in Ponta Grossa/PR, Fransozo et al. (2003) observed that this period, for the same species, in Itatinga, São Paulo state, occurs from October to December and Gonçalves et al. (2006), in their studies with A. franciscana, in the municipality of São Francisco de Paula, located in the highlands of the Rio Grande do Sul state, observed recruitment during the summer, but mention that the recruitment might have occurred in the spring or summer of the former year, given the large size of the sampled juveniles, that differed markedly from recently hatched young.

The present study contributed to the understanding of the life cycle of $A$. manuinflata in the Passo Taquara stream, central region of the Rio Grande do Sul state, as well as for the understanding of aeglids in a broader sense. Due to the fact that this species has only recently been described, many aspects of its biology must still be investigated, so that we can understand its life history more accurately.

\section{Acknowledgements}

We thank CAPES and CNPq for the masters and research scholarships granted for the first and second author, respectively. To the Programa de Pós Graduação em Biodiversidade Animal (UFSM) and the team of the Laboratory of Carcinology of the Universidade Federal de Santa Maria for their aid in the field work. 


\section{References}

ADIYODI, KG. and ADIYODI, RG. 1970. Endocrine control of reproduction in decapod Crustacea. Biological Review, vol. 45, no. 2, p. 121-165. PMid:4915582. http://dx.doi.org/10.1111/j.1469185X.1970.tb01627.x

ALMERÃO, M., BOND-BUCKUP, G. and MENDONÇA Jr., MS. 2010. Mating behavior of Aegla platensis (Crustacea, Anomura, Aeglidae) under laboratory conditions. Journal of Ethology, vol. 28 , no. 1, p. 87-94. http://dx.doi.org/10.1007/ s10164-009-0159-7

AYRES, M., AYRES JÚNIOR, M., AYRES, DL. and SANTOS, AA. 2007. BIOESTAT: aplicações estatísticas nas áreas das ciências bio-médicas. Belém: Ong Mamiraua.

BAHAMONDE, N. and LOPEZ, MT. 1961. Estudios biologicos en la populacion de Aegla laevis laevis (Latreille) de el Monte (Crustacea, Decapoda, Anomura). Investigaciones Zoológicas Chilenas, vol. 7, p. 19-58.

BAPTISTA, C., PINHEIRO, MAA., BLANKENSTEYN, A. and BORZONE, CA. 2003. Estrutura populacional de Callinectes ornatus Ordway (Crustacea, Portunidae) no Balneário de Shangri-Lá, Pontal do Paraná, Paraná, Brasil. Revista Brasileira de Zoologia, vol. 20, no. 4, p. 661-666. http://dx.doi. org/10.1590/S0101-81752003000400018

BARTHOLOMEI-SANTOS, ML., RORATTO, PA. and SANTOS, S. 2011. High genetic differentiation of Aegla longirostri (Crustacea, Decapoda, Anomura) populationsin southern Brazil revealed by multi-loci microsatellite analysis. Genetics and Molecular Research, vol. 10, no. 4, p. 4133-4146. PMid:22179994. http://dx.doi.org/10.4238/2011.November.22.4

BEGON, M. 1979. Investigating animal abundance: capture-recapture for biologist. London: Edward Arnold. 97 p.

BRADSHAW, CJA., GIAM, X., TAN, HTW., BROOK, BW. and SODHI, NS. 2008. Threat or invasive status in legumes is related to opposite extremes of the same ecological and life-history attributes. Journal of Ecology, vol. 96, no. 5, p. 869-883. http://dx.doi. org $/ 10.1111 / j .1365-2745.2008 .01408 . x$

BRANCO, LO. and FRACASSO, HAA. 2004. Biologia populacional de Callinectes ornatus (Ordway) na Armação do Itapocoroy, Penha, Santa Catarina, Brasil. Revista Brasileira de Zoologia, vol. 21, no. 1, p. 91-96. http://dx.doi.org/10.1590/S010181752004000100016

BUENO, AAP. and BOND-BUCKUP, G. 2000. Dinâmica populacional de Aegla platensis Schmitt (Crustacea, Decapoda, Aeglidae). Revista Brasileira de Zoologia, vol. 17, no. 1, p. 43-49. http://dx.doi. org/10.1590/S0101-81752000000100005
BUENO, AAP., BOND-BUCKUP, G. and BUCKUP, L. 2000. Crescimento de Aegla platensis em ambiente natural (Crustacea, Decapoda, Aeglidae). Revista Brasileira de Zoologia, vol. 17, no. 1, p. 51-60. http:// dx.doi.org/10.1590/S0101-81752000000100006

BUENO, SLS., SHIMIZU, RM. and ROCHA, SS. 2007. Estimating the population size of Aegla franca (Decapoda: Anomura: Aeglidae) by markrecapture technique from an isolated section of Barro Preto stream, county of Claraval, State of Minas Gerais, southeastern Brazil. Journal of Crustacean Biology, vol. 27, no. 4, p. 553-559. http://dx.doi. org/10.1651/S-2762.1

BUENO, SLS. and SHIMIZU, RM. 2008. Reproductive biology and functional maturity in females of Aegla franca (Decapoda: Anomura: Aeglidae). Journal of Crustacean Biology, vol. 28, no. 4, p. 652-662. http:// dx.doi.org/10.1651/07-2974.1

COHEN, FPA., TAKANO, BF., SHIMIZU, RM. and BUENO, SLS. 2011. Life cycle and population structure of Aegla paulensis (Decapoda: Anomura: Aeglidae). Journal of Crustacean Biology, vol. 31, no. 3, p. 389-395. http://dx.doi.org/10.1651/103415.1

COLPO, KD., RIBEIRO, LD. and SANTOS, S. 2005. Population biology of the freshwater Anomura Aegla longirostri (Aeglidae) from South Braziliam streams. Journal of Crustacean Biology, vol. 25, no. 3, p. 495499. http://dx.doi.org/10.1651/C-2543

DÍAZ, H. and CONDE, JE. 1989. Population dynamics and life of mangrove crab Aratus pisonii (Brachyura, Grapsidae) in a marine environment. Bolletin of Marine Science, vol. 45, no. 1, p. 148-163.

FRANSOZO, A., COSTA, RC., REIGADA, ALD. and NAKAGAKI, JM. 2003. Population structure of Aegla castro Schmitt, 1942 (Crustacea: Anomura: Aeglidae) from Itatinga (SP), Brazil. Acta Limnologica Brasiliensia, vol. 15, no. 2, p. 13-20.

GIAM, X., NG, TH., LOK, AFSL. and NG, HH. 2011. Local geographic range predicts freshwater fish extinctions in Singapore. Journal of Applied Ecology, vol. 48, no. 2, p. 356-363. http://dx.doi. org/10.1111/j.1365-2664.2010.01953.x

GIESEL, JT. 1972. Sex ratio, rate of evolution, and environmental heterogeneity. American Naturalist, vol. 106, no. 949, p. 380-387. http://dx.doi. org/10.1086/282777

GONÇALVES, RS., CASTIGLIONI, DS. and BOND-BUCKUP, G. 2006. Ecologia populacional de Aegla franciscana (Crustacea, Decapoda, Anomura) em São Francisco de Paula, RS, Brasil. Iheringia Série Zoologia, vol. 96, no. 1 p. 109-114. http://dx.doi. org/10.1590/S0073-47212006000100019 
HARTNOLL, RG. 1982. Growth. In BLISS, DE., ed. The biology of Crustacea. New York: Academic Press. p. 111-196.

International Union for Conservation of Nature - IUCN. 2013. IUCN red list categories: version 3.1. Cambridge: IUCN.

LÓPEZ, MT. 1965. Estudios biologicos en Aelga odebrechtii paulensis, Schmitt (Crustacea, Decapoda, Anomura). Boletin de Zoologia, Faculdade de Filosofia, Ciências e Letras, vol. 25, p. 301-315.

MARKUS, R. 1971. Elementos de estatística aplicada. Porto Alegre: Faculdade de Agronomia e Veterinária da UFRGS/Centro Acadêmico Leopoldo Cortez. $329 \mathrm{p}$.

MARTIN, JW. and ABELE, LG. 1986. External morphology of the genus Aegla (Crustacea: Anomura: Aeglidae). Washington: Smithsonian Institution Press. 46 p. (Smithsonian Contributions to Zoology, no. 453).

MASUNARI, S. 2006. Distribuição e abundância dos caranguejos Uca Leach (Crustacea, Decapoda, Ocypodidae) na Baía de Guaratuba, Paraná, Brasil. Revista Brasileira de Zoologia, vol. 23, no. 4, p. 901-914. http://dx.doi.org/10.1590/S010181752006000400001

MONTAGUE, CL. 1980. A natural history of temperate western Atlantic fiddler crabs (Genus $U c a$ ) with reference to their impact on the salt marsh. Contributions of Marine Science, vol. 23, p. 25-55.

NEGREIROS-FRANSOZO, ML., MANTELATTO, FLM. and FRANSOZO, A. 1999. Population biology of Callinectes ornatus Ordway, 1863 (Decapoda, Portunidae) from Ubatuba (SP), Brazil. Scientia Marina, vol. 63, no. 2, p. 157-163.

NORO, CK. and BUCKUP, L. 2002. Biologia reprodutiva e ecologia de Aegla leptodactyla Buckup and Rossi, 1977 (Crustacea, Anomura, Aeglidae). Revista Brasileira de Zoologia, vol. 19, no. 4, p. 1063-1074. http://dx.doi.org/10.1590/S010181752002000400011

OLDEN, JD., POFF, NL. and BESTGEN, KR. 2008. Traitsynergisms and the rarity, extirpation, and extinction risk of desert fishes. Ecology, vol. 89, no. 3, p. 847-856. PMid:18459347. http://dx.doi. org/10.1890/06-1864.1

PASSANO, LM. 1960. Molting and its control. In TALBOT, HW., ed. The physiology of Crustacea: metabolim and growth. New York: Academic Press. p. $473-536$

RANDS, MRW., ADAMS, WM., BENNUN, L., BUTCHART, SHM., CLEMENTS, A., COOMES, D., ENTWISTLE, A., HODGE, I., KAPOS, V., SCHARLEMANN, JPW., SUTHERLAND, WJ. and VIRA, B. 2010. Biodiversity conservation: challenges beyond 2010. Science, vol. 329, no. 5997, p. 12981303. http://dx.doi.org/10.1126/science.1189138
RODRIGUES, W. and HEBLING, NJ. 1978. Estudos biológicos em Aegla perobae Hebling and Rodrigues, 1977 (Decapoda, Anomura). Revista Brasileira de Biologia, vol. 38, no. 2, p. 383-390.

SANTOS, S., BOND-BUCKUP, G., PÉREZLOSADA, M., BARTHOLOMEI-SANTOS, ML. and BUCKUP, L. 2009. Aegla manuinflata, a new species of freshwater anomuran (Decapoda: Anomura: Aeglidae) from Brazil, determined by morphological and molecular characters. Zootaxa, vol. 2088, p. 31-40.

SNEDECOR, GW. and COCHRAN, WG. 1967. Statistical methods. 6th ed. Ames: Iowa State University Press.

SWIECH-AYOUB, BP. and MASUNARI, S. 2001a. Biologia reprodutiva de Aegla castro Schmitt (Crustacea, Anomura, Aeglidae) no Buraco do Padre, Ponta Grossa, Paraná, Brasil. Revista Brasileira de Zoologia, vol. 18, no. 3, p. 1019-1030. http://dx.doi. org/10.1590/S0101-81752001000300033

SWIECH-AYOUB, BP. and MASUNARI, S. $2001 \mathrm{~b}$. Flutuaçóes temporal e espacial de abundância e composição de tamanho de Aegla castro Schmitt (Crustacea, Anomura, Aeglidae) no Buraco do Padre, Ponta Grossa, Paraná, Brasil. Revista Brasileira de Zoologia, vol. 18, no. 3, p. 1003-1017. http://dx.doi. org/10.1590/S0101-81752001000300032

TEODÓSIO, EAO. and MASUNARI, S. 2009. Estrutura populacional de Aegla schmitti (Crustacea: Anomura: Aeglidae) nos reservatórios dos Mananciais da Serra, Piraquara, Paraná, Brasil. Zoologia, vol. 26, no. 1, p. 19-24. http://dx.doi.org/10.1590/S198446702009000100004

TREVISAN, A., HEPP, LU. and SANTOS, S. 2009. Abundância e distribuição de Aeglidae (Crustacea: Anomura) em funçáo do uso da terra na bacia hidrográfica do Rio Jacutinga, Rio Grande do Sul, Brasil. Zoologia, vol. 26, no. 3, p. 419-426.

TREVISAN, A. and SANTOS, S. 2012. Morphological sexual maturity, sexual dimorphism and heterochely in Aegla manuinflata (Anomura). Journal of Crustacean Biology, vol. 32, no. 4, p. 519-527. http://dx.doi. org/10.1163/193724012X635944

TROTT, TJ. 1996. On the sex ratio of the painted ghost crab Ocypode gaudichaudii H. Milne Edwards \& Lucas, 1843 (Brachyura, Ocypodidae). Crustaceana, vol. 71, no. 1, p. 47-56.

WENNER, AM. 1972. Sex-ratio as a function of size in marine Crustacea. American Naturalist, vol. 106, no. 949, p. 321-350. http://dx.doi. org/10.1086/282774

ZAR, JH. 1996. Biostatistical analysis. New Jersey: Prentice-Hall. 662 p. 